\title{
The Metabolism of Acetate by the Blue-green Algae, Anabaena variabilis and Anacystis nidulans
}

\author{
By J. PEARCE AND N. G. CARR \\ Department of Biochemistry, University of Liverpool, Liverpool, England
}

(Accepted for publication 22 May 1967)

\begin{abstract}
SUMMAR Y
The utilization of acetate by blue-green algae was examined and the activities of enzymes involved in its metabolism measured. Although acetate did not stimulate the endogenous respiration of these organisms, the oxidation of acetate was followed by the rate of release of $\left[{ }^{14} \mathrm{C}\right]$ carbon dioxide from $\left[\mathrm{I}^{14} \mathrm{C}\right]$ and $\left[2-{ }^{14} \mathrm{C}\right]$ sodium acetate. Similarly, sodium acetate did not alter the rate of growth of Anabaena variabilis and Anacystis nidulans but in A. variabilis it was found to contribute $7 \cdot 2 \%$ of the dry weight when cultures were gassed with air $+\mathrm{CO}_{2}(95+5, \mathrm{v} / \mathrm{v})$, and $\mathrm{I} 6.9 \%$ when gassed with air alone. The presence of acetate in the growth medium did not alter the activity of the acetate-activating enzymes, glyoxylate cycle enzymes or two tricarboxylic acid cycle enzymes. The failure to show enzyme adaption by these organisms when supplied with an exogeneous substrate is discussed in relation to their hitherto apparently autotrophic nature.
\end{abstract}

\section{INTRODUCTION}

The blue-green algae, in spite of diverse ecological distribution, have markedly uniform nutrition. Most of the species examined are considered to be strict photoautotrophs (Allen, 1952) and their failure to respond to external carbon sources other than carbon dioxide has been noted by many workers. Exceptions to this statement include Tolypothrix tenius, the growth of which is stimulated by glucose (Kiyohara et al. 1960; 1962) and Chlorogloea fritschii, which has been reported to grow in the dark on sucrose albeit the growth rate was expressed in terms of months rather than days (Fay, 1965). The incorporation of $\left[{ }^{14} \mathrm{C}\right]$ acetate into Nostoc muscorum and transformation into lipids has been known for some years (Allison et al. 1953); Hoare \& Moore (1965) described the photoassimilation of acetate by three blue-green algae and also showed major incorporation to be into the lipid fraction. The fact that Chlorogloea fritschii forms poly- $\beta$-hydroxybutyrate only when grown in the presence of acetate, also indicates the utilization of this substrate by a blue-green alga (Carr, I966). We therefore decided to examine in the blue-green algae the metabolism of acetate at the whole organism and enzymic levels. Some preliminary results of this investigation have already been reported (Carr \& Pearce, 1966; Pearce \& Carr, 1966).

\section{METHODS}

Organisms. We are grateful to the following for gifts of the cultures of the blue-green algae used: Anabaena variabilis (Kützing) from Professor J. Myers, Department of Zoology, University of Texas, Austin, Texas; Anacystis nidulans from the collection 
of Dr M. B. Allen through the courtesy of Dr A. A. Horton, Department of Biochemistry, University of Birmingham; Chlorogloea fritschii from Professor G. E. Fogg, Department of Botany, Westfield College, University of London, London. All organisms were maintained on agar $(2 \%)$ slopes of the mineral salt medium (see below) supplemented with sodium acetate (Io mM) and yeast extract (Difco, I \%).

Growth. The algae were grown on a mineral salt medium (Medium C, Kratz \& Myers, $1955 a)$ to which $\mathrm{NaHCO}_{3}(0.05 \%)$ had been added. Sodium acetate (20 mM) was added where indicated in the text. Cultures for experimental purposes were grown in Carrel flasks (penicillin pots) at $34^{\circ}$ in $500 \mathrm{ml}$. medium illuminated by $30 \mathrm{~W}$ warm white daylight strip lights and gassed with air $+\mathrm{CO}_{2}(95+5$, by vol. $)$ as previously described (Carr \& Hallaway, 1965). The growth of each organism was determined turbidimetrically in an EEL colorimeter by comparison with a previously prepared calibration curve relating EEL reading to dry weight of organism.

Incorporation of $\left[{ }^{14} \mathrm{C}\right]$ labelled acetate. Experiments involving $\left[\mathrm{U}-{ }^{14} \mathrm{C}\right]$ acetate were carried out in $20 \mathrm{ml}$. volumes but otherwise under the conditions described above. $\left[{ }^{14} \mathrm{C}\right]$ carbon dioxide was released from $\left[{ }^{14} \mathrm{C}\right]$ sodium bicarbonate by $5 \mathrm{~N}-\mathrm{HCl}$ and pumped through the algal cultures in a closed system which recycled the gas phase. The extent of isotopic incorporation was measured in a harvested and thoroughly washed (six times) suspension by counting, after drying, at infinite thinness in a Nuclear-Chicago Gas-Flow Automatic Planchette Counter. Each sample was counted in duplicate to an accuracy of $2 \%$.

Manometry. Logarithmic phase cultures were harvested, the organism, washed and resuspended in sterile growth medium $\left(\mathrm{pH}_{7} \cdot 4\right)$ or $0^{\circ} \mathrm{I}$ M-potassium phosphate buffer $(\mathrm{pH} 7 \cdot 0)$ and oxygen uptake measured at $34^{\circ}$ by the direct procedure and expressed as $\mathrm{Q}_{\mathrm{o}_{2}}(\mu \mathrm{l} . / \mathrm{mg}$. dry $\mathrm{wt} / \mathrm{hr})$ with and without the addition of sodium acetate $(30 \mathrm{~mm})$. In experiments involving $\left[\mathrm{I}-{ }^{14} \mathrm{C}\right]$ acetate and $\left[2-{ }^{14} \mathrm{C}\right]$ acetate double side-arm Warburg flasks were used which contained hyamine hydroxide (Snyder \& Godfrey, 196I) in the centre well instead of $\mathrm{NaOH}$, sodium acetate $\left[{ }^{14} \mathrm{C}\right]$ in one side arm and $0.5 \mathrm{ml}$. sodium dodecylsulphate $(10 \%)$ in the other. At various times the respiration was stopped by adding sodium dodecylsulphate. After $45 \mathrm{~min}$, to allow complete absorption of carbon dioxide by the hyamine hydroxide, the contents of the centre well were transferred by syringe to $5 \mathrm{ml}$. of scintillation fluid and counted in a Packard Tri-Carb Liquid Scintillation Spectrometer Series 3I4E to an accuracy of at least $2 \%$.

Preparation of cell-free extracts. Organisms were harvested during the logarithmic phase of growth, washed once with distilled water and resuspended in $0.1 \mathrm{M}$-phosphate buffer $\left(\mathrm{pH} 7^{\circ} \mathrm{o}\right.$ ) to a final con centration equiv. 30-60 mg. dry wt $/ \mathrm{ml}$. Organisms were broken by $(a)$ extrusion through a French pressure cell at I0,000 lb./sq. in., or $(b)$ ultrasonic distintegration in an M.S.E. $60 \mathrm{~W}$., $20 \mathrm{Kc} / \mathrm{sec}$. sonic disintegrator for three 45 -sec. periods. In either case a temperature of $\mathrm{o}-2^{\circ}$ was maintained and enzyme activities were similar in extracts prepared by either means. Cell-wall debris and unbroken organisms were removed by centrifugation at $10,000 \mathrm{~g}$ for $15 \mathrm{~min}$. at $0^{\circ}$, yielding an intensely green supernatant fluid of cell-free extract.

\section{Estimations}

Acetyl-CoA synthetase. [EC. 6.2.I.I]. This was assayed by the procedure of Jones \& Lipmann (1955). The reaction mixture contained, in $\mu$ moles, potassium phosphate

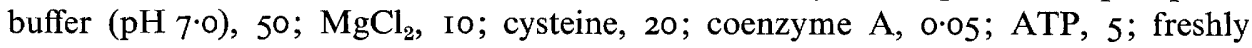


neutralized hydroxylamine, I000; sodium acetate, 200 ; in a total volume $\mathrm{I} \cdot 5 \mathrm{ml}$. The reaction was done at $34^{\circ}$ and initiated by the adding of cell-free extract containing 5-10 $\mathrm{mg}$. protein. Hydroxamic acid formation was estimated by the increase in extinction at $540 \mathrm{~m} \mu$ after the adding of the $\mathrm{FeCl}_{3}$ reagent.

Acetate kinase. [E.C. 2.7.2. I]. The synthesis of acetylphosphate was determined, after reaction with neutralized hydroxylamine, by the formation of a $\mathrm{FeCl}_{3}$ complex as above. The composition of the reaction mixture was the same as that for the assay of acetyl-CoA synthetase except that coenzyme A was omitted.

Phosphotransacetylase [E.C. 2.3.I.8]. This enzyme was measured by following the disappearance of acetylphosphate when incubated with coenzyme $\mathrm{A}$ in the presence of arsenate (Stadtman, 1952). The reaction mixture contained, in $\mu$ moles, potassium

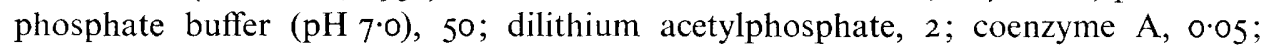
cysteine, I0; potassium arsenate, 50;5-10 mg. protein in a total volume of $2.0 \mathrm{ml}$. At intervals the residual acetylphosphate was determined by the hydroxamic acid procedure of Lipmann \& Tuttle (1945).

Citrate synthase [E.C. $4 \cdot 1 \cdot 3 \cdot 7$ ] Where acetate kinase and phosphotransacetylase were the means of activating acetate (i.e. in extracts of Anabaena variabilis) citrate synthase was measured by the disappearance of acetylphosphate in the presence of coenzyme A and oxaloacetate using the procedure of Ochoa (I955). Acetylphosphate was estimated as the hydroxamic acid and an appropriate control permitted a correction for the small amount of acetyl-CoA metabolized by deacylation. In extracts of Anacystis nidulans in which acetate is activated directly by acetyl-CoA synthetase a different procedure was adopted (Srere, Brazil \& Gonen, 1963). This involved the assay of coenzyme A released from acetyl-CoA on condensation with oxaloacetate. The sulphydryl group of coenzyme A reacts with 5,5'-dithiobis-[2-nitrobenzoic acid] to yield 2-nitro-5-mercaptide benzoate which has an extinction maximum at $4 \mathrm{I} 2 \mathrm{~m} \mu$.

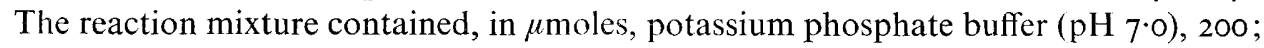
acetyl-coenzyme $\mathrm{A}, 0.05 ; \mathrm{MgCl}_{2}$, Io; cysteine, 20; 5,5-'dithiobis-[2-nitrobenzoic acid], $20 ; 3-5 \mathrm{mg}$. protein in a total volume of $2.5 \mathrm{ml}$. The reaction was initiated by adding Io $\mu$ moles oxaloacetate.

Isocitrate dehydrogenase [E.C. I.I. I.42]. This was assayed by following the rate of reduction of NADP in the presence of isocitrate according to the method of Ochoa (1948). The reaction mixture contained, in $\mu$ moles, potassium phosphate buffer $\left(\mathrm{pH} 7 \cdot 0\right.$ ), $200 ; \mathrm{MnCl}_{2}, 5$; NADP, 0.5 ; extract (containing $3-5 \mathrm{mg}$. protein) in a total volume of $2.5 \mathrm{ml}$. After the addition of $10 \mu$ moles isocitrate the rate of reduction of NADP was followed at $340 \mathrm{~m} \mu$.

Isocitrate lyase [E.C. 4.I.3.I]. The incubation of isocitrate with algal extracts results in the formation of keto acid phenylhydrazones linearly with time. The identity of the keto acid formed was examined by incubation in the presence of semicarbazide and conversion of the resulting semicarbazone to the 2,4-dinitrophenylhydrazone, Extraction into ethyl acetate by the method of Friedemann \& Haugen (1943) and chromatography showed the presence of the 2,4-dinitrophenylhydrazones of glyoxylate and $\alpha$-ketoglutarate. The production of glyoxylate from isocitrate was confirmed by formation of a compound spectrally identical with that of 1,5-diphenylformazan carboxylic acid which is produced from glyoxylate phenylhydrazone under acid conditions (Kramer, Klein \& Baselice, 1959). We concluded, therefore, that in our extracts the standard procedure of Dixon \& Kornberg (I959) did not eliminate the 
action of isocitrate dehydrogenase. Attempts to remove the endogenous pyridine nucleotide or to maintain it in a reduced form did not satisfactorily resolve the problem. Physical separation of isocitrate lyase and isocitrate dehydrogenase was achieved by centrifugation of the crude cell-free extract at $78,000 \mathrm{~g}$ for $20 \mathrm{hr}$. The fraction containing isocitrate lyase activity did not contain any isocitrate dehydrogenase activity. The isocitrate lyase activity of this fraction was assayed according to Dixon \& Kornberg (1959). The reaction mixture contained, in $\mu$ moles, potassium phosphate buffer ( $\mathrm{pH} 7 \cdot 0$ ), 200; cysteine, $20 ; \mathrm{MgCl}_{2}, 10$; phenylhydrazine, 20 ; and $0.3-0.5 \mathrm{mg}$. protein in a total volume of $2.5 \mathrm{ml}$. The reaction was initiated by the addition of 20 $\mu$ moles DL-isocitrate and the formation of glyoxylate phenylhydrazone followed at $324 \mathrm{~m} \mu$.

Malate synthase [E.C. 4.I.3.2]. With the Unicam S.P. 700 recording spectrophotometer and cell-free extracts of blue-green algae it was not possible to assay this enzyme by the standard procedure (Dixon \& Kornberg, 1959) based on the decline of extinction at $232 \mathrm{~m} \mu$ due to the disappearance of the thiolester bond of acetylCoA. Accordingly, a method was devised based on the rate of disappearance of glyoxylate (measured as its phenylhydrazone at $324 \mathrm{~m} \mu$ ) when incubated with acetylCoA or ATP, coenzyme A and sodium acetate. When the cell-free extract was treated with Dowex-I- $\times 4$ (50-I00 mesh; $\mathrm{Cl}-$ form), which removed endogenous coenzyme A, there was no decrease in the amount of glyoxylate in the reaction mixture in the absence of added coenzyme A. A series of $5 \times \frac{5}{8}$ in. test tubes contained, in $\mu$ moles, potassium phosphate buffer $(\mathrm{pH} 7 \cdot 0) 50 ; \mathrm{MgCl}_{2}$, I0; cysteine, 20; coenzyme A, 0.05; ATP, 5; sodium acetate, 200; sodium glyoxylate, 0.06 ; in a total volume of $2 \cdot 0 \mathrm{ml}$. The assay was done at $34^{\circ}$ and initiated by the addition of cell-free extract containing $3.7 \mathrm{mg}$. protein. The enzymic reaction was stopped at intervals $(5,10,15,20,30$, $40 \mathrm{~min}$.) by adding $\mathrm{I} \mathrm{ml} .10 \%(\mathrm{w} / \mathrm{v})$ trichloroacetic acid and $0 . \mathrm{I} \mathrm{ml}$. phenylhydrazine $\mathrm{HCl}(0.2 \mathrm{M})$ and the extinction at $324 \mathrm{~m} \mu$ determined after removal of the precipitated protein.

Protein estimation. The amount of protein in cell-free extracts was determined colorimetrically by a method based on the biuret reaction (Layne, 1957). The photosynthetic pigments were removed prior to protein estimation by hot acid-ethanol (Vernon \& Kamen, 1953). The colour produced was determined at $550 \mathrm{~m} \mu$ and compared with a standard of crystalline bovine serum albumen.

Chemicals. ATP, coenzyme A, NADP and NAD were obtained from C. F. Boehringer Ltd. (Mannheim, Germany); dilithium acetyl phosphate and 5,5'-dithiobis[2-nitrobenzoic acid] from the Sigma London Chemical Company Ltd. (I 2 Lettice St., London, S.W.6); sodium dodecylsulphate from K \& K Laboratories, Inc. (I7710 93rd Avenue, Jamaica 33, New York); hyamine hydroxide (molar solution in methanol) from Packard Instrument Ltd. (IO-I 2 St. Johns Road, Wembley, Middlesex). All other chemicals were purchased from British Drug Houses Ltd. (Poole, Dorset) and were the purest commercial grade available. Radioactive sodium acetate $\left(\left[\mathrm{I}-{ }^{14} \mathrm{C}\right],\left[2-{ }^{14} \mathrm{C}\right]\right.$ and $\left.\left[\mathrm{U}-{ }^{14} \mathrm{C}\right]\right)$, and $\left[2^{-14} \mathrm{C}\right]$ sodium glyoxylate were purchased from $T$ The Radiochemical Centre, Amersham, Buckinghamshire. 


\section{RESULTS}

\section{Growth and respiratory studies}

Short-term experiments. When the minimal salt (autotrophic) medium was supplemented with sodium acetate (20 mM) neither Anabaena variabilis nor Anasystis nidulans exhibited a significantly higher rate of growth. Variation of the concentration of sodium acetate (10-50 mm) was without effect and attempts to grow A. variabilis in the presence of sodium acetate and absence of carbon dioxide were unsuccessful. The failure of acetate and other substrates to stimulate respiration in blue-green algae has been known for some time (Kratz \& Myers, 1955b) and in our experiments A. variabilis was no exception. Over a range of $\mathrm{pH}$ values $(4 \cdot 3-8 \cdot 0)$ the endogenous rate of respiration of this organism was not significantly affected by the addition of sodium acetate to a concentration of $30 \mathrm{~mm}$. The oxygen uptake by $A$. nidulans was slightly stimulated by the addition of glucose. Comparison of respiratory rates in the mineral salt medium and $0.1 \mathrm{M}$-potassium phosphate buffer $(\mathrm{pH} 7 \cdot 0)$ showed that the growth medium was a superior environment for respiration by suspensions of washed organisms. When the organisms were starved of carbon dioxide for $4 \mathrm{hr}$ immediately before harvesting, the rate of endogenous respiration was decreased; the rate of respiration was largely restored by the addition of sodium acetate or glucose; other organic compounds had less effect (Table I).

Table 1. Effect of various organic compounds on the respiration of Anabaena variabilis and Anacystis nidulans

\begin{tabular}{|c|c|c|c|}
\hline \multirow[b]{2}{*}{ Organism } & \multirow[b]{2}{*}{ Addition $[30 \mathrm{~mm}]$} & \multicolumn{2}{|c|}{$\underbrace{\mathrm{Q}_{2}}_{\mathrm{O}_{2}}$} \\
\hline & & $a^{*}$ & $b^{*}$ \\
\hline A. variabilis & $\begin{array}{l}\text { None } \\
\text { Sodium acetate } \\
\text { Glucose } \\
\text { Sodium pyruvate } \\
\text { Sucrose }\end{array}$ & $\begin{array}{l}12 \cdot 3 \\
11 \cdot 7 \\
13 \cdot 1 \\
12 \cdot 7 \\
11 \cdot 2\end{array}$ & $\begin{array}{l}3 \cdot 08 \\
2 \cdot 9 \\
3 \cdot 5 \\
3 \cdot 2 \\
3 \cdot 17\end{array}$ \\
\hline $\begin{array}{l}\text { A. variabilis } \\
\text { (starved of } \mathrm{CO}_{2} \\
\text { for } 4 \mathrm{hr} \text { before } \\
\text { harvest) }\end{array}$ & $\begin{array}{l}\text { None } \\
\text { Sodium acetate } \\
\text { Glucose } \\
\text { Sucrose } \\
\text { Sodium pyruvate }\end{array}$ & $\begin{array}{l}3 \cdot 62 \\
11 \cdot 8 \\
8 \cdot 63 \\
6 \cdot 4 \\
4 \cdot 1\end{array}$ & $\begin{array}{l}- \\
- \\
-\end{array}$ \\
\hline A. nidulans & $\begin{array}{l}\text { None } \\
\text { Sodium acetate } \\
\text { Glucose }\end{array}$ & - & $\begin{array}{l}6 \cdot 8 \\
8 \cdot 9 \\
9 \cdot 8\end{array}$ \\
\hline
\end{tabular}

* (a) manometry in minimal salt medium; $(b)$ manometry in $0 \cdot 1$ M-potassium phsphate buffer $(\mathrm{pH} 7 \cdot 0)$.

The metabolism of $\left[\mathrm{I}^{14} \mathrm{C}\right]$ acetate and $\left[2-{ }^{14} \mathrm{C}\right]$ acetate was examined by measurement of the $\left[{ }^{14} \mathrm{C}\right]$ carbon dioxide evolved during respiration (Fig. I). The more rapid release of $\left[{ }^{14} \mathrm{C}\right]$ carbon dioxide from $\left[\mathrm{I}^{14} \mathrm{C}\right]$ acetate is consistent with the operation of a tricarboyxlic acid cycle. However, the ratio of radioactivity from the carboxyl group as compared with the methyl group was somewhat greater than expected. This may indicate the presence of another route of acetate oxidation apart from the tricarboxylic acid cycle. The marked alteration in the rate of $\left[{ }^{14} \mathrm{C}\right]$ carbon dioxide production from $\left[\mathrm{I}^{-14} \mathrm{C}\right]$ acetate after about $\mathrm{I} \mathrm{hr}$ may be due to possible direction of acetate into another 
pathway or to the exhaustion of $\mathrm{C}_{4}$ intermediates. The corollary of these results are shown in Fig. 2, which shows that $\left[2-{ }^{14} \mathrm{C}\right]$ acetate was more effectively incorporated in cellular material of $A$. variabilis than was $\left[\mathrm{I}^{14} \mathrm{C}\right]$ acetate when incubated under identical conditions to those employed in the manometric experiments. It is noteworthy that the uptake of $\left[{ }^{14} \mathrm{C}\right]$ acetate over the first hour was the same irrespective of light or darkness or the position of the labelled carbon in the acetate. This observation was consistent over three experiments and may be due to a period of equilibration where the rate of entry of the acetate molecules was the same in each case and was great enough to mask the subsequent metabolism of the acetate.
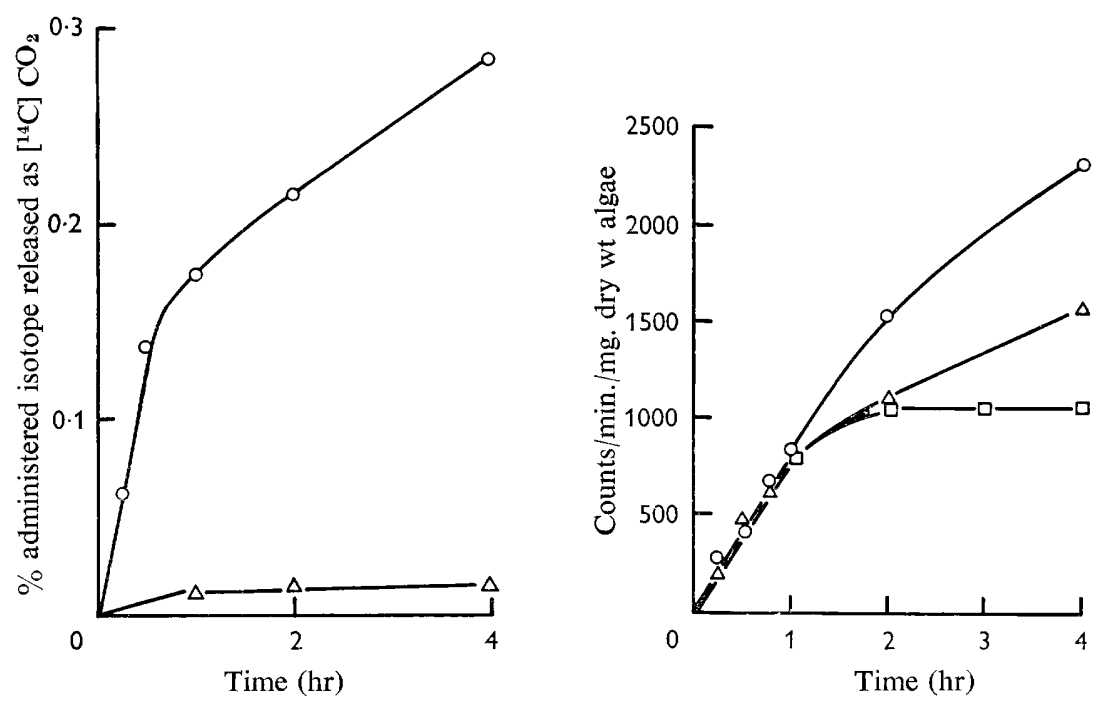

Fig. I. The rate of release of $\left[{ }^{14} \mathrm{C}\right] \mathrm{CO}_{2}$ from $\left[\mathrm{I}-{ }^{14} \mathrm{C}\right]$ acetate and $\left[2-{ }^{14} \mathrm{C}\right]$ acetate by Anabaena variabilis in the dark. The experiment was done as described in Methods. To the suspensions of algae (equiv. $20 \mathrm{mg}$. dry wt $/ \mathrm{ml}$.) were added $100 \mu$ moles sodium acetate containing $2 \mu \mathrm{C}$ $\left[2-{ }^{14} \mathrm{C}\right]$ sodium acetate $(-\mathrm{O}-\mathrm{O}--)$, or $2 \mu \mathrm{C}\left[\mathrm{I}{ }^{14} \mathrm{C}\right]$ sodium acetate $(-\triangle-\triangle-)$.

Fig. 2. Degree of incorporation of $\left[\mathrm{I}^{14} \mathrm{Clacetate}\right.$ and $\left[2-{ }^{14} \mathrm{C}\right] \mathrm{acetate}$ into Anabaena variabilis in the light and the dark. The experiment was done in $150 \mathrm{ml}$. conical flasks containing $20 \mathrm{ml}$. volumes of medium $\mathrm{C}$ supplemented with sodium acetate. The flasks were incubated at $34^{\circ}$, gently shaken and illuminated by a IOO W tungsten lamp at a distance of 9 inches. The rates of incorporation of $\left[2^{-14} \mathrm{C}\right]$ acetate in the light $(-\mathrm{O}-\mathrm{O}-)$, and in the dark $(-\square-\square-)$, are compared with the rate of $\left[\mathrm{r}^{14} \mathrm{C}\right]$ acetate in the light $(-\Delta-\Delta-)$.

Long-term experiments. Although there was no stimulation of the growth or respiration of Anabaena variabilis by the addition of sodium acetate, the entry of $\left[\mathrm{U}-{ }^{14} \mathrm{C}\right] \mathrm{acetate}$ into the organisms was shown and its incorporation measured. After 7 days' growth, $7 \cdot 2 \%$ of the total dry weight of $A$. variabilis was derived from the $\left[\mathrm{U}-{ }^{14} \mathrm{C}\right.$ ]acetate supplementing the growth medium. When the normal gas phase of air $+\mathrm{CO}_{2}(95+5, \mathrm{v} / \mathrm{v})$ was replaced by one of air alone, $\left[\mathrm{U}-{ }^{14} \mathrm{C}\right]$ acetate accounted for $16.7 \%$ of the total dry weight of organism. These figures indicate the degree of acetate assimilation and do not take into account any respired $\left[\mathrm{U}^{14} \mathrm{C}\right]$ acetate. Further evidence that exogenous sodium acetate was being appreciably incorporated into $A$. variabilis was provided by the depression of $\left[{ }^{14} \mathrm{C}\right]-\mathrm{CO}_{2}$ incorporation into growing cultures when the growth medium was supplemented with $20 \mathrm{~mm}$-sodium acetate. 


\section{Enzymic activities}

In agreement with Hoare \& Moore (1965) we found that Anacystis nidulans activated acetate directly by acetyl-CoA synthetase, this process being dependent on the presence of CoA. The same enzyme was found in Chlorogloea fritschii. Anabaena variabilis, however, formed acet-hydroxamate in the absence of coenzyme-A, and the formation of acetyl-CoA was mediated by the two enzymes, acetate kinase and phosphotransacetylase. The identity of the enzymic product was examined by co-chromatography of the hydroxamate formed with chemically prepared acet-hydroxamate. After growth in the presence of sodium acetate $(20 \mathrm{mM})$, the specific activities of the enzymes were measured in cell-free extracts and compared with those obtained with cell-free extracts of autotrophically grown organisms (Table 2). There was no appreciaable difference in any of the enzyme activities measured. The estimation of acetyl-CoA

\section{Table 2. Enzymes of acetate activation}

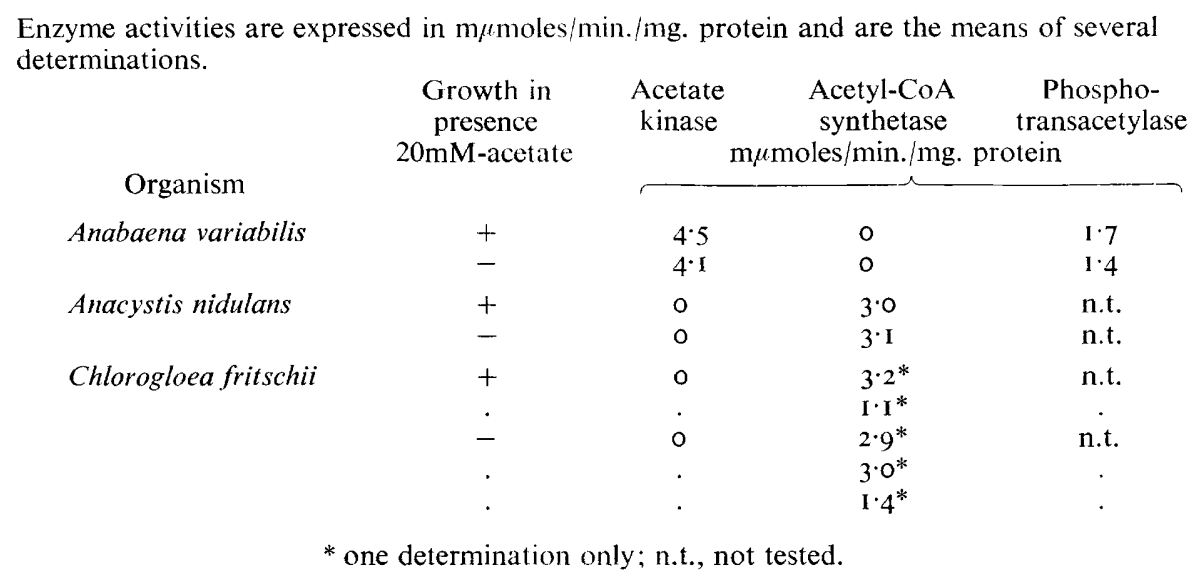

synthetase in $C$. fritschii preparations gave variable results; a possible explanation of this was the tendency of the organism to clump during growth, thus preventing the development of a uniform culture. The effect of decreasing the amount of $\mathrm{CO}_{2}$ available to $A$. variabilis was examined in the presence and absence of sodium acetate $(20 \mathrm{~mm})$. The growth rate was decreased when the normal gas mixture (air $+\mathrm{CO}_{2}$, $95+5, \mathrm{v} / \mathrm{v}$ ) was replaced by air alone. Growth under these conditions was not stimulated by sodium acetate, neither was acetate kinase activity increased.

The two key enzymes of the glyoxylate by-pass were measured as described in Methods. It was necessary to separate isocitrate lyase from the relatively highly active isocitrate dehydrogenease in extracts of Anabaena variabilis and Anacystis nidulans; this was achieved by centrifugation at $78,000 \mathrm{~g}$ for $20 \mathrm{hr}$. This resulted in the formation of two bands in the supernatant fluid of the extract; an upper yellow region which was shown to contain isocitrate lyase activity but no isocitrate dehydrogenase activity, and a larger phycocyanin-containing region which held most of the isocitrate dehydrogenase activity. The absence of NADP reduction in the presence of isocitrate by the yellow fraction is shown in Fig. $3 a$, indicating that this fraction did not possess isocitrate dehydrogenase activity. However, the presence of isocitrate lyase activity in 
the yellow fraction was indicated by the formation of a phenylhydrazone, absorbing at $324 \mathrm{~m} \mu$, when isocitrate was added (Fig. $3 b$.) This enzyme was specific for NADP, no activity being shown with NAD. The isocitrate lyase activity was further characterized by the inhibition effected by sodium succinate (Fig. 4) and noted previously (Smith \& Gunsalus, 1957). Malate synthase activity was assayed as described in Methods by following the rate of glyoxylate disappearance in the presence of an acetyl-CoA forming system (Fig. 5). When coenzyme A was omitted from the reaction mixture and endogenous coenzyme A removed from the extract by Dowex treatment there was no decline in the amount of glyoxylate. Anaerobic incubation of $\left[2-{ }^{14} \mathrm{C}\right] \mathrm{glyoxy}-$ late (Io $\mu \mathrm{c} / \mu \mathrm{mole}$ ) in the assay system described, followed by chromatography of
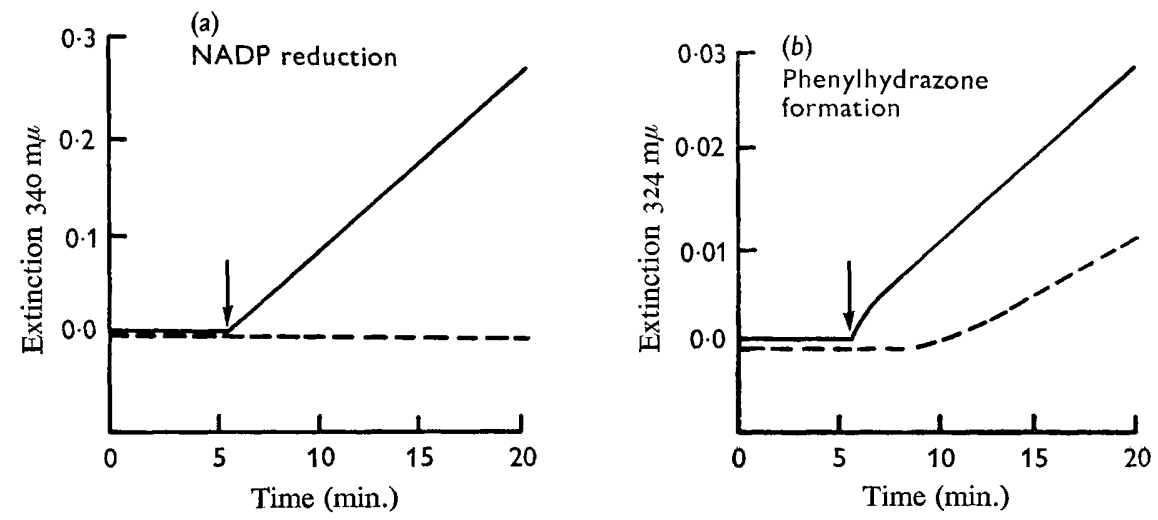

Fig. 3. Relative isocitrate dehydrogenase and isocitrate lyase activities of the yellow and blue regions of the ultracentrifuged extract of Anacystis nidulans. The assays for isocitrate dehydrogenase activity and isocitrate lyase activity were done as described in Methods. (a) NADP reduction. Isocitrate added at arrow to assay mixtures containing samples (equiv. I. $5 \mathrm{mg}$. protein) of the blue region (region (- - -). (b) Phenylhydrazone formation. Isocitrate added at the arrow to assay mixtures containing samples (equiv. $1.5 \mathrm{mg}$. protein) of the blue region ($0.28 \mathrm{mg}$. protein) of the yellow region (- - -).

the products, showed the major product to be malate with a smaller amount of citrate. Anaerobic conditions were used in this confirmatory experiment to minimize any subsequent metabolism of the isotopically-labelled malate. Extracts were prepared from $A$. variabilis and $A$. nidulans after growth in the presence or absence of sodium acetate $(20 \mathrm{~mm})$ and no difference in isocitrate lyase or malate synthase activity was found (Table 3 ). Very similar degrees of activity were present in extracts from either organism.

Two enzymes of the tricarboxylic acid cycle were also determined in extracts prepared from cultures grown in the presence or absence of acetate. These enzymes also showed no alteration in activity after growth with acetate (Table 4). The constant activity of citrate synthase is perhaps particularly interesting, serving as it does as the major entry point of acetate into the tricarboxylic cycle. The marked difference in activity of citrate synthase in extracts of Anabaena variabilis and Anacystis nidulans might be the result of procedural variations or species differences. The method of estimation used with $A$. nidulans involved the use of 5,5'-dithiobis-[2-nitrobenzoic acid] which we found to inhibit the analogous enzyme, malate synthase. 
The blue-green algae examined did not adjust the enzymes metabolizing acetate when grown in the presence of sodium acetate. Preliminary results indicate that ribulose diphosphate carboxylase activity, the key enzyme of photosynthetic $\mathrm{CO}_{2}$ fixation, was slightly altered after growth in the presence of sodium acetate. The growth rate of Anabaena variabilis was decreased to about half the control value by

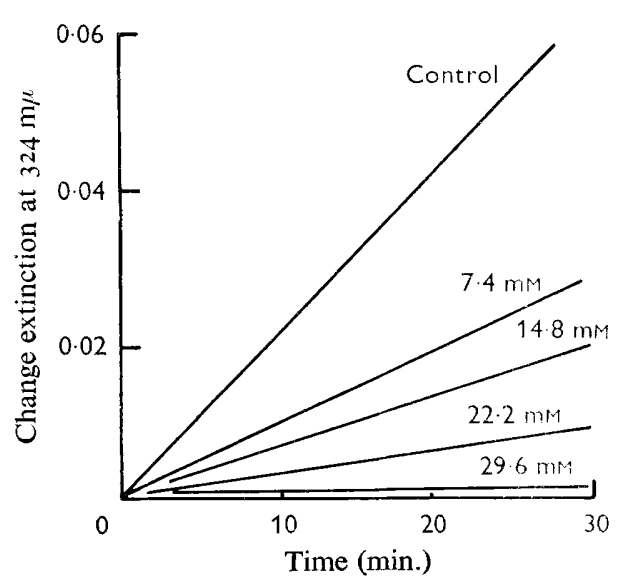

Fig. 3

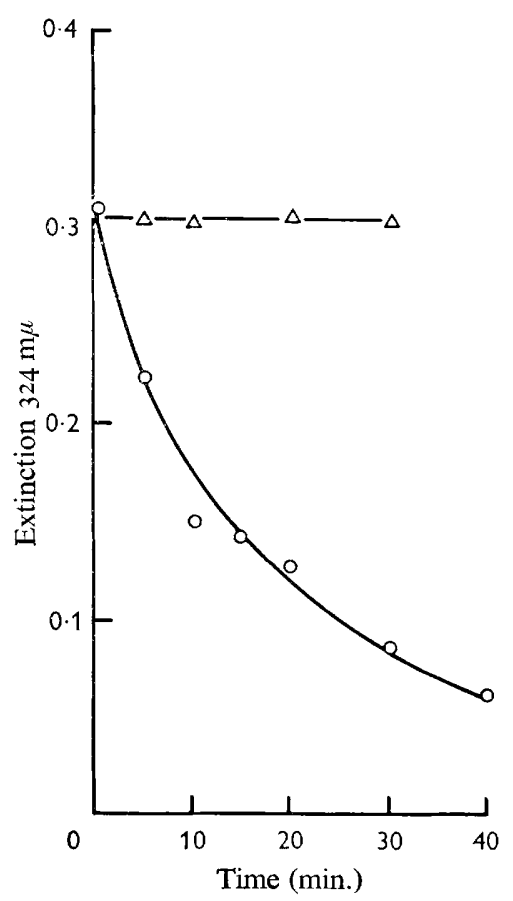

Fig. 4

Fig. 4. Inhibition of isocitrate lyase activity in extracts of Anabaena variabilis by sodium succinate. The assay was done as described in Methods and sodium succinate added at the concentrations indicated. The assay mixture contained equiv. $0.68 \mathrm{mg}$. protein in a total volume of $2.7 \mathrm{ml}$.

Fig. 5. Disappearance of glyoxylate in the presence and absence of coenzyme A. The assay for malate synthase activity in Anacystis nidulans was done as described. The residual glyoxylate was measured as its phenylhydrazone at $324 \mathrm{~m} / \iota$ after incubation with Dowex-treated cellfree extract (containing $3.2 \mathrm{mg}$. protein). The assay was done in the presence $(-\mathrm{O}-\mathrm{O}-$ ) and the absence $(-\triangle-\triangle-)$ of added coenzyme $A$.

Table 3. Glyoxylate cycle in the blue-green algae Anabaena variabilis and Anacystis nidulans

Enzyme activities expressed in m $\mu$ moles/min./mg. protein and are the mean of several determinations.

Organism

A. variabilis

A. nidulans
Growth in presence Isocitrate $20 \mathrm{~mm}$ acetate lyase

$\begin{array}{ll}+ & 0.38 \\ - & 0.39 \\ + & 0.45 \\ - & 0.43\end{array}$

Malate synthase

0.82

0.80

I.07

I. 00 
interposing neutral filters between the culture vessel and light source, thus decreasing the available illumination. Under these conditions of light limited growth, $\left[\mathrm{U}-{ }^{14} \mathrm{C}\right]$ acetate $(20 \mathrm{mM})$ was incorporated to the same extent as in the control and the activities of acetate kinase, isocitrate lyase and isocitrate dehydrogenase were unaltered (Table 5).

Table 4. Activities of two tricarboxylic acid cycle enzymes

Enzyme activities expressed in m $\mu$ moles $/ \mathrm{min} . / \mathrm{mg}$. protein and are the average of several determinations.

$\begin{array}{cccc}\text { Organism } & \begin{array}{c}\text { Growth in } \\ \text { presence } \\ 20 \mathrm{mM} \text { acetate }\end{array} & \begin{array}{c}\text { Isocitrate } \\ \text { dehydrogenase }\end{array} & \begin{array}{c}\text { Citrate } \\ \text { synthase }\end{array} \\ \text { Anabaena variabilis } & + & 5.0 & 6 . \mathrm{I}^{*} \\ \text { Anacystis nidulans } & - & 4.7 & 5.7^{*} \\ & + & 16.7 & 0.67 \dagger \\ & - & 16.5 & 0.70 \dagger\end{array}$

* Procedure of Ochoa, (1955); $\uparrow$ Procedure of Srere, Brazil \& Gonen, (I963).

Table 5. Anabaena variabilis: growth and enzyme activities under light-limiting conditions

Enzyme activities expressed as m $/$ moles/min./mg. protein.

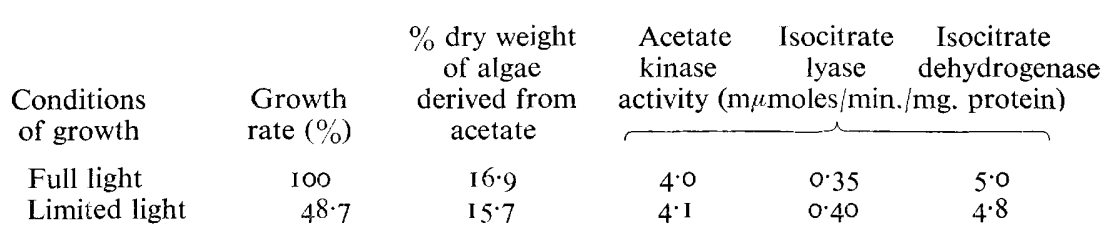

DISCUSSION

The general autotrophic nature of blue-green algae has been known for many years and the occasional early reports of heterotrophic growth of certain species are often considered to be a result of impure cultures or incorrect classification. Allen (1952), in a detailed examination of the growth requirements of thirty blue-green algae, concluded that one species did require organic compounds in the growth medium, and the growth rate of several other species was improved in their presence. It appeared likely that these compounds were not serving as nutrients in themselves, but assisted in the absorption of certain mineral elements. Kratz \& Myers (1955 b), using three species of blue-green algae (including Anabaena variabilis and Anacystis nidulans), showed that there was only a limited respiratory response to a wide range of organic substrates. These workers postulated that a permeability barrier limited the ready availability of exogenous substrates to these organisms, a suggestion that had already been applied to other autotrophic micro-organisms. Studies in our laboratory showed that four species of blue-green algae were permeable to dichlorophenolindophenol (Carr \& Hallaway, 1965), although it is appreciated that permeability of microbial cell membranes is a highly selective phenomenon and it is quite possible for an organism to permit entry of a complex dye molecule and still be impermeable 
to small organic substrates. The metabolism of acetate by blue-green algae appeared to be a fruitful level at which to consider the apparent autotrophic nature of the microorganisms studied.

The data presented confirms earlier reports that acetate does not increase the growth or respiratory rate of the blue-green algae examined. However, experiments with $\left[\mathrm{U}-{ }^{14} \mathrm{C}\right]$ acetate indicates that incorporation occurs and that acetate contributes a significant fraction of the total dry cell weight. Similarly respiration of $\left[\mathrm{I}^{14} \mathrm{C}\right]$ and $\left[2-{ }^{14} \mathrm{C}\right]$ sodium acetate was demonstrated, the proportion of $\left[{ }^{14} \mathrm{C}\right] \mathrm{CO}_{2}$ released from each position being compatible with oxidation via the tricarboxylic acid cycle. It is evident that Anabaena variabilis and Anacystis nidulans are permeable to sodium acetate and possess enzymes necessary for its metabolism. The presence or absence of acetate in the growth medium did not alter the activities of acetate activating, glyoxylate cycle or two tricarboxylic acid cycle enzymes (Tables 2, 3, 4). The levels of isocitrate lyase in both $A$. variabilis and $A$. nidulans are low compared to those in other micro-organisms; this may indicate that another route of acetyl-CoA metabolism is operative. Following the incorporation of $\left[{ }^{14} \mathrm{C}\right]$ acetate, Hoare \& Moore (I965) did not find evidence of glyoxylate cycle operation in $A$. nidulans.

These results are in contrast to those obtained in many other microbial species where the inclusion of acetate in the growth medium increases the activity of enzymes concerned in its metabolism. The adaptive nature of isocitrate lyase has been shown in a large number of micro-organisms (see Kornberg \& Elsden, 196I). The activity of this enzyme increased after growth in the presence of acetate. Likewise, in the green alga, Chlorella vulgaris isocitrate lyase and malate synthase increase in activity several fold after growth in the presence of acetate (Syrett, Merrett \& Bocks, 1963). Perhaps the most pertinent comparison of the results presented is with the levels of enzyme activities in the facultative autotroph, Hydrogenomonas sp. strain $\mathrm{HI} 65^{+}$, after growth on acetate, or on $\mathrm{H}_{2}$ and $\mathrm{CO}_{2}$ (Trüper, 1965). All the enzymes examined in the blue-green algae here increased at least several fold after growth of Hydrogenomonas on acetate as compared with $\mathrm{CO}_{2}$ and $\mathrm{H}_{2}$. Isocitrate lyase activity was fifteen-fold higher, and acetyl-CoA synthetase six-fold higher after growth on acetate. When Hydrogenomonas was grown on fructose each of the enzymes discussed were significantly less active than after growth on acetate.

The failure to detect evidence of enzyme de-repression in blue-green algae, when acetate is added to the growth medium is unlikely to be due to a permanent repressing effect of $\mathrm{CO}_{2}$, since replacement of air $+\mathrm{CO}_{2}(95+5 \mathrm{v} / \mathrm{v})$ mixture by air alone did not cause any increase in enzyme activity, However, if all the $\mathrm{CO}_{2}$ in the gas phase was removed the culture died, so this point could not be established unequivocally. Similar attempts were made to induce increased enzyme activity in the presence of acetate by growing Anabaena variabilis under light-limiting conditions, which presumably reduced the pools of ATP and other high-energy phosphate esters to a minimum, but again thcre was no increase in the enzyme activities measured. It may be suggested that the lack of response exhibited to acetate, and other organic substrates, by bluegreen algae could be due to a failure to adjust enzyme complement to environmental change.

Recently the utilization of carbon containing molecules other than $\mathrm{CO}_{2}$ has been demonstrated in hitherto 'autotrophic' bacteria, Nitrobacter agilis (Ida \& Alexander, 1965), Thiobacillus thiooxidans (Butler \& Umbreit, 1966). It is evident that some 
species of both blue-green algae and bacteria previously considered capable of using only $\mathrm{CO}_{2}$ as a source of cell material can, at least under certain circumstances, use some organic molecules.

These studies were supported in part by Grant AM 05282-04 from the U.S. Department of Public Health. J.P. acknowledges receipt of a University of Liverpool Research Studentship.

\section{REFERENCES}

Allen, M. B. (1952). The cultivation of Myxophyceae. Arch. Mikrobiol. 17, 34.

Allison, R. K., Skipper, H. E., Reid, M. R., Short, W. A. \& Hogan, G. L. (I953). Studies on the photosynthetic reaction. I. The assimilation of acetate by Nostoc muscorum. J. biol. Chem. 204, 197.

Butler, R. G. \& Umbreit, W. W. (1966). Absorption and utilization of organic matter by the strict autotroph, Thiobacillus thiooxidans, with special reference to aspartic acid. J. Bact. 9r, 661 .

CARR, N. G. (1966). The occurrence of poly- $\beta$-hydroxybutyrate in the blue-green alga, Chloroglea fritschii. Biochim. Biophys. Acta 120, 308.

Carr, N. G. \& Hallaway, H. M. (I965). Reduction of phenolindo-2,6-dichlorophenol in dark and light by the blue-green alga, Anabaena variabilis. J. gen. Microbiol. 39, 335 .

Carr, N. G. \& Pearce, J. (I966). Photoheterotrophism in blue-green algae. Biochem. J. 99, 28 P.

Dixon, G. H. \& Kornberg, H. L. (1959). Assay methods for key enzymes of the glyoxylate cycle. Biochem. $J . \mathbf{7 2}, 3 \mathrm{P}$.

FAY, P. (1965). Heterotrophy and nitrogen fixation in Chlorogloea fritschii. J. gen. Microbiol. 39, I I.

Friedemann, T. E. \& Haugen, G. E. (1943). Pyruvic Acid. II. The determination of keto acids in blood and urine. J. biol. Chem. 147, 415 .

Hoare, D. S. \& MoOre, R. B. (I965). Photoassimilation of organic compounds by autotrophic bluegreen algae. Biochim. Biophys. Acta rog, 622.

IDA, S. \& AleXANDer, M. (1965). Permeability of Nitrobacter agilis to organic compounds. J. Bact. 90, I5I.

Jones, M. E. \& Lipmann, F. (1955). Enzymes of lipid metabolism. Aceto-CoA-kinase. Meth. Enzymol. $\mathbf{I}, 585$.

Kiyohara, T., Fujita, Y., Hattori, A. \& Watanabe, A. (1960). Heterotrophic culture of a bluegreen alga, Tolypothrix tenuis. I. J. gen. appl. Microbiol. 6, 176.

Kiyohara, T., Fujita, Y, Hattori, A. \& Watanabe, A. (1962). Effect of light on glucose assimilation in Tolypothrix tenuis. J. gen. appl. Microbiol. 8, I65.

KornberG, H. L. \& ElSDEN, S. R. (196I). The metabolism of 2-carbon compounds by micro organisms. Adv. Enzymol. 23, $40 \mathrm{I}$.

Kramer, D. N., Klein, N. \& Baselice, R. A. (1959). Quantitative determination of glyoxylic acid. Anal. Chem. 31, 250.

Kratz, W. A. \& MYers, J. (I955a). Nutrition and growth of several blue-green algae. Am. J. Bot. 42, 282.

Kratz, W. A. \& Myers, J. (I955 b). Photosynthesis and respiration of three blue-green algae. Plant Physiol. 30, 275.

LAYNE, E. (I957). Spectrophotometric and turbidimetric methods for measuring proteins. III. Biuret Method. Meth. Enzymol. r, 450.

Lipmann, F. \& TuttLe, L. C. (I945). A specific micromethod for the determination of acyl phosphates. J. biol. Chem. 159, 2 I.

OcHOA, S. (I948). Biosynthesis of tricarboxylic acids by carbon dioxide fixation. III. Enzymatic mechanisms. J. biol. Chem. 174, 133 .

OCHOA, S. (1955). Crystalline condensing enzyme from pig heart. In Meth. Enzymol. r, 685.

PeArce, J. \& CARR, N. G. (I966). Enzymes of acetate metabolism in blue-green algae. J. gen. Microbiol. 45, i.

Sмith, R. A. \& Gunsalus, I. C. (1957). Isocitratase: Enzyme properties and reaction equilibrium. J. biol. Chem. 229, 305. 
SNyder, F. \& Godfrey, P. (I96I). Collecting $\mathrm{C}^{14} \mathrm{O}_{2}$ in a Warburg flask for subsequent scintillation counting. J. Lipid Res. 2, 195.

Srere, P. A., BraziL, H. \& Gonen, L. ( I963). The citrate condensing enzyme of pigeon breast muscle and moth flight muscle. Acta Chem. Scand. 17, 129.

Stadtman, E. R. (1952). The purification and properties of phosphotransacetylase. J. biol. Chem. 196, 527.

Syrett, P. J., Merrett, M. J. \& Bocks, C. M. (1963). Enzymes of the glyoxylate cycle in Chlorella vulgaris. J. exp. Bot. 14, 249.

TRÜPER, H. G. (1965). Tricarboxylic acid cycle and related enzymes in Hydrogenomonas strain HI $6 \mathrm{G}^{+}$grown on various carbon sources. Biochim. Biophys. Acta III, 565.

Vernon, L. P. \& Kamen, M. D. (1953). Studies on the metabolism of photosynthetic bacteria. XV. Photoautoxidation of ferrocytochrome $\mathrm{C}$ in extracts of Rhodospirillum rubrum. Arch. Biochem. Biophys. 44, 298. 